Annals of Warsaw University of Life Sciences - SGGW

Land Reclamation No 40, 2008: 115-123

(Ann. Warsaw Univ. of Life Sci. - SGGW, Land Reclam. 40, 2008)

\title{
An analysis of physical, hydraulic and mechanic properties of nonwoven needle-punched geotextiles
}

\author{
DARIUSZ WOJTASIK \\ Department of Geotechnical Engineering, Warsaw University of Life Sciences - SGGW
}

\begin{abstract}
An analysis of physical, hydraulic and mechanic properties of needle-punched nonwoven geotextiles. This paper presents an analysis of technical parameters of needle-punched geotextiles used in engineering constructions. The tests were carried out in order to compare of physical, hydraulic and mechanic properties of needle-punched geotextiles in two different groups of products. First of group, geotextiles, were made of polypropylene fibers (PP) and the second one fabrics, were of polyester filaments (PES). The tests were performed for materials of mass per unit area 250,400 and $600 \mathrm{~g} / \mathrm{m}^{2}$. The results of test showed that parameters of geotextile material depend on structure of fabrics.
\end{abstract}

Key words: polyester geotextile, polypropylene geotextile.

\section{INTRODUCTION}

Dynamic development of artificial material caused that geotextiles products are one of the popular materials used in earth building constructions. The synthetic textiles used in soils perform many functions such as: reinforcement, separation, drainage and filtration. The geotextiles are usually made from synthetic polymers: polyester and polypropylene.

Polyester: The production process and material properties are influenced by the use of various additives such as catalysts, which increase the speed of polymerization, phosphatic compounds which reduce thermal degradation during processing in the molten stage and ageing inhibitors (including carbon black) which increase the U.V.-resistance.

Polypropylene: The polymerisation of propylene monomers in the presence of specific catalyst produces the crystalline thermoplastic polypropylene. It is very susceptible to oxidation and additives are required to protect against ageing, improve thermal stabilization, UV and underwater resistance (Yeo 2008).

Geotextiles can be classified as knitted, woven and nonwoven products. The woven and knitted geotextiles are usually thin products, which technical parameters are very well-defined (Rollin 1986). In nonwoven needlepunched materials it is not easy to determine technical parameters (e.g. apparent opening size). Many methods to determine and measured parameters of nonwoven geotextiles have been used in laboratory testing programs. Unfortunately the parameters in needlepunched geotextiles are not well understood and results obtained are quite different for a designed fabric.

In this study, physical, hydraulic and mechanical parameters of needlepunched geotextiles with about the same mass per unit area, made from one producer are discussed. The main objective of this paper is the comparison 
of the results of technical parameters of three polyester materials and three polypropylene geotextiles.

\section{MATERIAL}

For research were used six needlepunched geotextiles made of polyester and polypropylene fibers. These materials are widely used in engineering structures. Three polyester materials (PES) and three polypropylene fabrics (PP) were used in tests. Physical, hydraulic and mechanical parameters of geotextiles (from one producer) are tabulated in Table 1.

\section{METHODS}

The methods for determining technical parameters of geotextiles material are presented in Table 2.

TABLE 1. Physical, hydraulic and mechanical properties of geotextiles

\begin{tabular}{|c|c|c|c|c|c|c|c|c|}
\hline \multirow{3}{*}{\begin{tabular}{|l} 
Properties \\
Physical \\
Mass per unit area \\
Thickness under \\
load $2 \mathrm{kPa}$ \\
Apparent Opening \\
Size
\end{tabular}} & \multirow{2}{*}{$\begin{array}{c}\begin{array}{c}\text { Sym- } \\
\text { bol }\end{array} \\
\mu_{\mathrm{A}}\end{array}$} & \multirow{2}{*}{$\begin{array}{c}\text { Unit } \\
{\left[\mathrm{g} / \mathrm{m}^{2}\right]}\end{array}$} & \multicolumn{6}{|c|}{ Geotextiles } \\
\hline & & & \multicolumn{3}{|c|}{$\begin{array}{l}\text { Polyester } \\
\text { (PES) }\end{array}$} & \multicolumn{3}{|c|}{$\begin{array}{l}\text { Polypropylene } \\
\text { (PP) }\end{array}$} \\
\hline & $\begin{array}{c}\mu_{\mathrm{A}} \\
\mathrm{t}_{\mathrm{GTX}} \\
\mathrm{O}_{90}\end{array}$ & $\begin{array}{c}{\left[\mathrm{g} / \mathrm{m}^{2}\right]} \\
{[\mathrm{mm}]} \\
{[\mathrm{mm}]} \\
\end{array}$ & $\begin{array}{l}250 \\
2.5 \\
0.11\end{array}$ & $\begin{array}{l}400 \\
3.5 \\
0.81\end{array}$ & $\begin{array}{r}600 \\
4,0 \\
0.89\end{array}$ & $\begin{array}{l}250 \\
2.6 \\
0.11 \\
\end{array}$ & $\begin{array}{l}400 \\
3.7 \\
0.10\end{array}$ & $\begin{array}{r}600 \\
4.9 \\
0.81\end{array}$ \\
\hline $\begin{array}{l}\text { Hydraulic } \\
\text { Velocity flow } \\
\text { index (normal } \\
\text { to the plane } \\
\text { geotextiles) } \\
\text { Transmissivity } \\
\text { flow } \\
\text { (gradient, i }=0.1 \\
\text { under load } 2 \mathrm{kPa} \text { ) } \\
\text { - Machine } \\
\text { direction (normal) } \\
\text { - Machine } \\
\text { direction (cross) }\end{array}$ & $\begin{array}{l}\Theta_{\text {md. }} \\
\Theta_{\text {cmd }}\end{array}$ & $\begin{array}{l}{\left[\mathrm{m}^{2} / \mathrm{s}\right]} \\
{\left[\mathrm{m}^{2} / \mathrm{s}\right]}\end{array}$ & $\begin{array}{c}2.2 \\
\times 10^{-3} \\
\\
1.2 \\
\times 10^{-3}\end{array}$ & $\begin{array}{l}3.3 \times 10^{-6} \\
3.2 \times 10^{-6}\end{array}$ & $\begin{array}{l}4.4 \times 10^{-3} \\
9.1 \times 10^{-3}\end{array}$ & $\begin{array}{l}8.2 \times 10^{-} \\
3 \\
\begin{array}{c}1.5 \times 10^{-} \\
2\end{array}\end{array}$ & $\begin{array}{l}1.2 \times 10^{-2} \\
1.8 \times 10^{-2}\end{array}$ & $\begin{array}{l}8.4 \times 10^{-3} \\
9.5 \times 10^{-3}\end{array}$ \\
\hline $\begin{array}{l}\text { Mechanical } \\
\text { Tensile strength } \\
\text { - Machine } \\
\text { direction (cross) } \\
\text { - Machine } \\
\text { direction (normal) } \\
\text { Static puncture } \\
\text { by means CBR } \\
\text { method } \\
\text { Dynamic puncture }\end{array}$ & $\begin{array}{l}\mathrm{T}_{\mathrm{cmd}} \\
\mathrm{T}_{\mathrm{mc}} \\
\mathrm{F}_{\mathrm{p}}\end{array}$ & $\begin{array}{c}{[\mathrm{kN} / \mathrm{m}]} \\
{[\mathrm{kN} / \mathrm{m}]} \\
{[\mathrm{kN}]}\end{array}$ & $\begin{array}{l}10 \\
15 \\
2\end{array}$ & $\begin{array}{l}18 \\
28 \\
3.5\end{array}$ & $\begin{array}{l}26 \\
42 \\
4.8\end{array}$ & $\begin{array}{c}9 \\
13 \\
1.7\end{array}$ & $\begin{array}{l}16 \\
22 \\
3.0\end{array}$ & $\begin{array}{l}18 \\
13 \\
2.8\end{array}$ \\
\hline
\end{tabular}


TABLE 2.The norms used to test geotextiles materials

\begin{tabular}{|l|c|}
\hline Properties & Norms \\
\hline Physical & \\
Mass per unit area & PN-EN ISO 9864 \\
Thickness under load $[\mathrm{kPa}]$ & PN-EN ISO 9863 \\
Apparent Opening Size & PN-EN ISO 12956 \\
\hline Hydraulic & \\
Velocity flow index (normal to the plane geotextiles) & PN-EN ISO 11058 \\
Transmissivity flow & PN-EN ISO 12958 \\
\hline Mechanical & \\
Tensile strength & PN-EN ISO 10319 \\
Static puncture by means CBR method, & PN-EN ISO 12236 \\
Dynamic puncture & PN-EN ISO 13433 \\
\hline
\end{tabular}

\section{RESULT AND DISCUSSION}

The results of tested technical properties of geotextiles are divided into three parts:

\section{Physical properties of geotextiles}

The changes of bulk density, for tested geotextiles under loads: 2,20 and 200 $\mathrm{kPa}$ are showed in Figure 1. The bulk densities (Fig. 1) for both tested materials depend on values of strength of load. Geotextiles made of polypropylene (PP) had lower values of bulk density then values of bulk density of polyester fabric (PES).

The bulk density in geotextiles may be calculated using (Krzywosz et al. 2001):

$\rho_{d}=\frac{\mu_{A}}{t_{G T X}} \quad\left[\mathrm{~kg} / \mathrm{m}^{3}\right]$

where:

$\mu_{A}-$ mass per unit area $\left[\mathrm{g} / \mathrm{m}^{2}\right]$,

$\mathrm{t}_{G T X}$ - thickness for the applied load of geotextiles [mm].

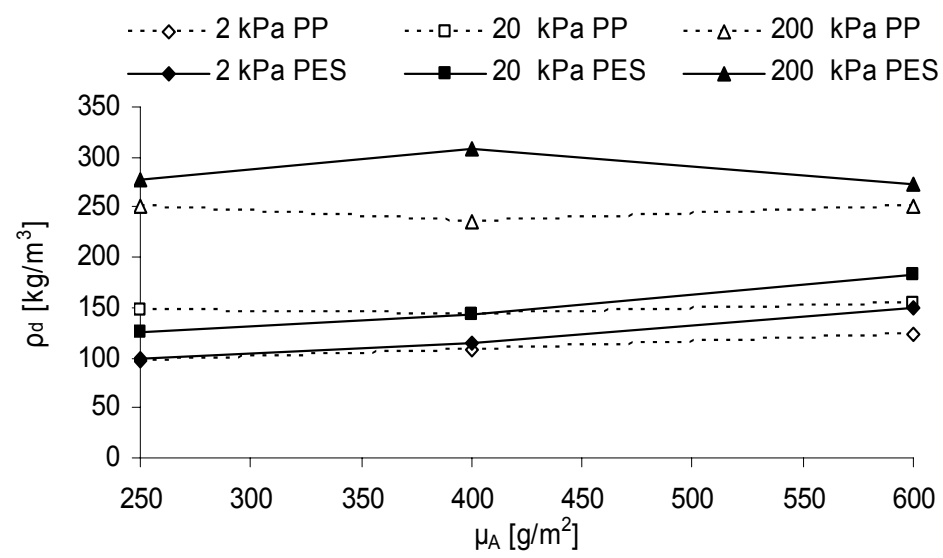

FIGURE 1 . The change of bulk density $\left(\rho_{\mathrm{d}}\right)$ of geotextiles under load between mass per unit area $\left(\mu_{\mathrm{A}}\right)$ of tested material 
The changes of thickness of geotextiles under load between mass per unit area of geotextiles are presented in Figure 2. The values of thickness of tested geotextiles were highest for polypropylene material (PP) for each mass per unit area of fabric. The highest values of thickness were observed for geotextiles with about mass per unit area $\mu_{A}=600 \mathrm{~g} / \mathrm{m}^{2}$.

Results of tested porosity in geotextiles under load showed in Figure 3. The values of porosity for both materials decrease when mass per unit of these materials increase. Polypropylene geotextiles showed more values of porosity compared to porosity values of polyester geotextiles.

The variation of apparent opening size in geotextiles tests is presented in Figure 4. Results of $\mathrm{O}_{90}$ depended on geotextile porosity. There can be observed similar trends of result of tested different geotextile products. The values of apparent opening size in tested

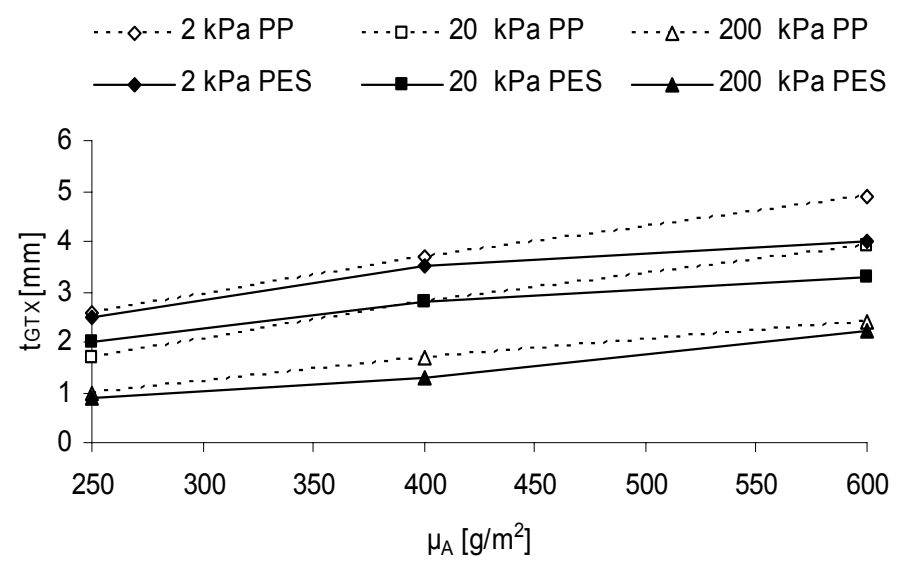

FIGURE 2. The change of thickness of geotextiles $\left(t_{\mathrm{GTX}}\right)$ under load between mass per unit area $\left(\mu_{\mathrm{A}}\right)$ of tested material

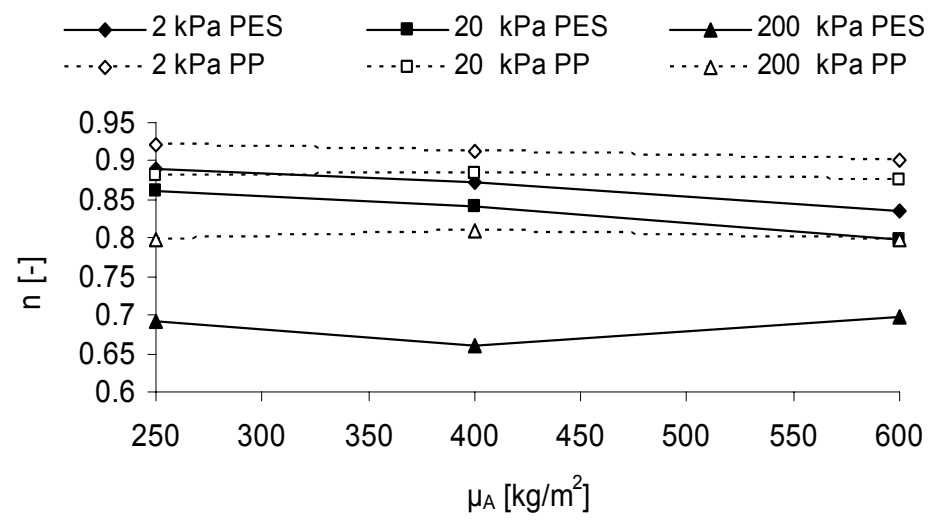

FIGURE 3. The change of porosity under load of geotextiles (n) between mass per unit area $\left(\mu_{\mathrm{A}}\right)$ of tested material 


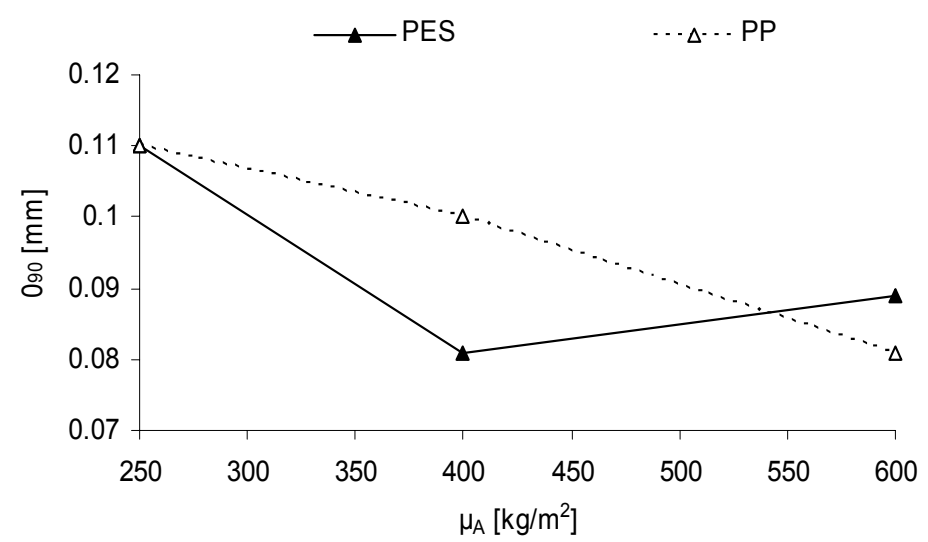

FIGURE 4 . The change of apparent opening size (090) between mass per unit area $\left(\mu_{\mathrm{A}}\right)$ of tested material

geotextiles decrease for materials which mass per unit area is higher.

\section{Hydraulic properties of geotextiles}

Ananalysis ofthehydraulic characteristic of geotextiles depended on the direction of water flow through the tested sample. There are two directions of flows: normal to the plane flow (perpendicular to the sample) and cross plane flow.
Water flow velocity index (v-normal to the plane) variations versus the mass per unit area of materials showed in Figure 5. The results of tested velocity index in Figure 5 show that mass per unit area can significantly affect hydraulic properties of the geotextiles.

Cross plane flow (transmissivity) can be estimated in two cases: normal and cross to the sample (Fig. 6). First of them is flow water in accordance with the machine direction $\left(\theta_{\mathrm{md}}\right)$ of fibers

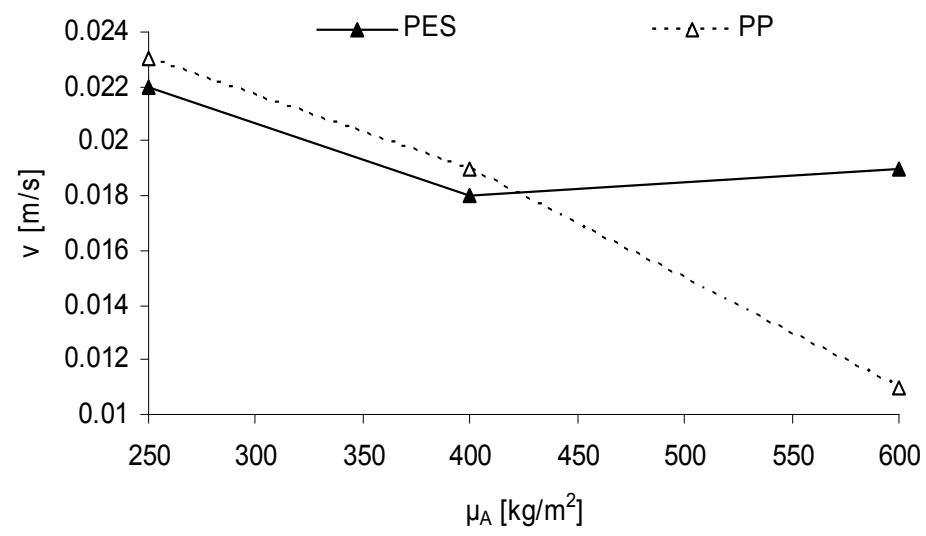

FIGURE 5. The change of velocity index flow ( $\mathrm{v}-$ normal to the plane flow) of geotextiles between mass per unit area $\left(\mu_{\mathrm{A}}\right)$ of tested material 


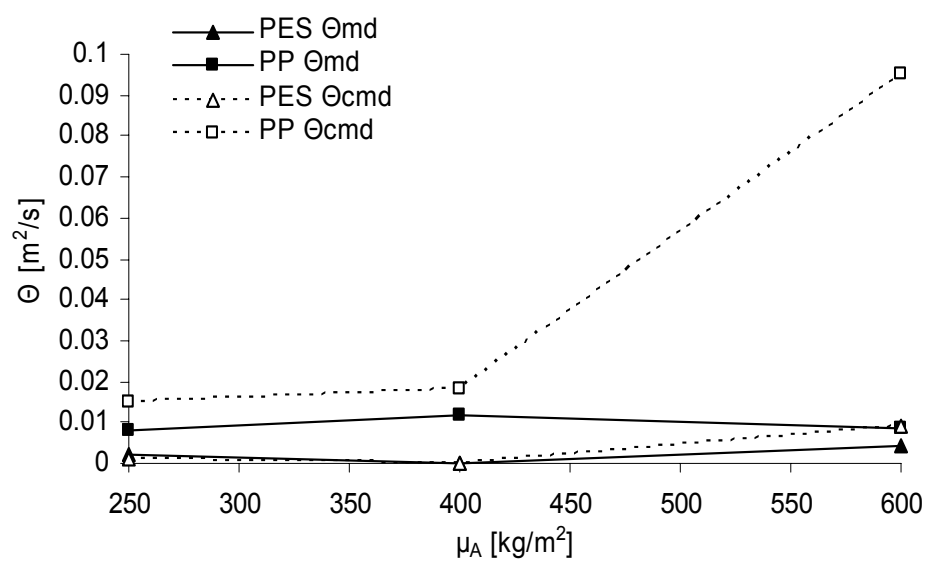

FIGURE 6 . The change of transmissivity flow water of geotextiles $\left(\theta_{\mathrm{md}}-\right.$ machine direction and $\theta_{\mathrm{cmd}}$ - cross machine direction) between mass per unit area $\left(\mu_{\mathrm{A}}\right)$ of tested material

in geotextile material and the second is flow suitable the cross machine direction $\left(\theta_{\text {cmd }}\right)$ of filaments in geotextiles.

Result of tested (Fig. 6) characteristic of flow water through the geotextiles samples indicate that values of transmissivity flow depend on technology of materials production. Flow water in cross machine direction in polypropylene geotextiles had higher values than in polyester geotextiles.

\section{Mechanical properties of geotextiles}

Figure 7 shows the comparison between results obtained from analyses tensile strength $\left(\mathrm{T}_{\mathrm{md}}-\right.$ machine direction and $\mathrm{T}_{\mathrm{cmd}}$ - cross machine direction).

The values of tensile strength of tested geotextiles increased in materials with higher values of mass per unit area. The analysis of tested geotextiles (Fig. 7) showed that tensile powers were totally different for each tested material.

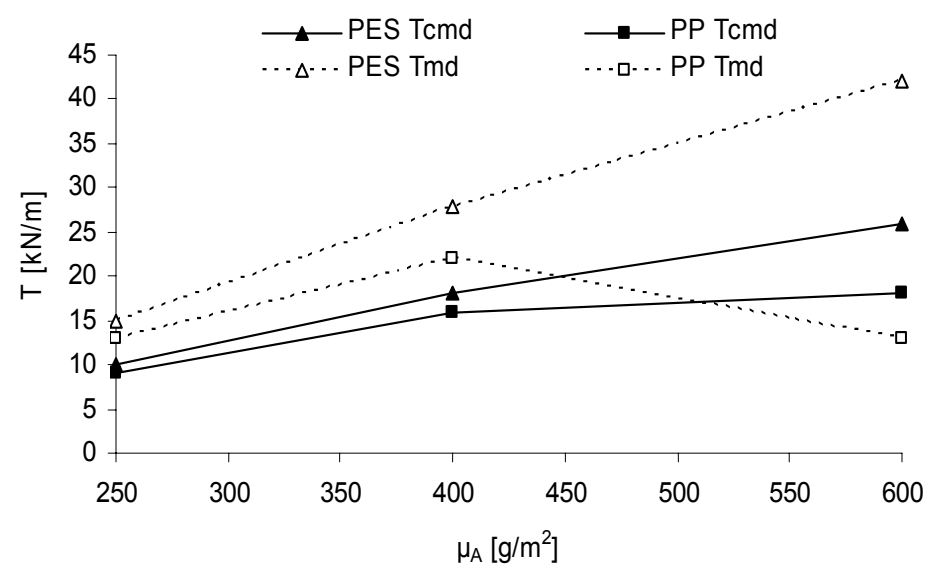

FIGURE 7. The change of tensile strength $(\mathrm{T})$ of geotextiles $\left(\mathrm{T}_{\mathrm{md}}-\right.$ machine direction and $\mathrm{T}_{\mathrm{cmd}}-$ cross machine direction) between mass per unit area $\left(\mu_{\mathrm{A}}\right)$ of tested material 
Another mechanical parameter of The values of it are totally different from tested geotextiles is static puncture (Fig. values of static puncture test. The higher 8 ). Results of tested static puncture showed values are observed in tested geotextiles that lower resistant of puncture was for fabric with lower mass per unit area. observed in polypropylene geotextiles. The values of dynamic punctures were The results of tested fabric indicate that decreasing when mass per unit area of static puncture increased when mass tested product increased. per unit area of tested geotextiles was highest.

The dynamic punctures of tested geotextiles are presented in Figure 9.

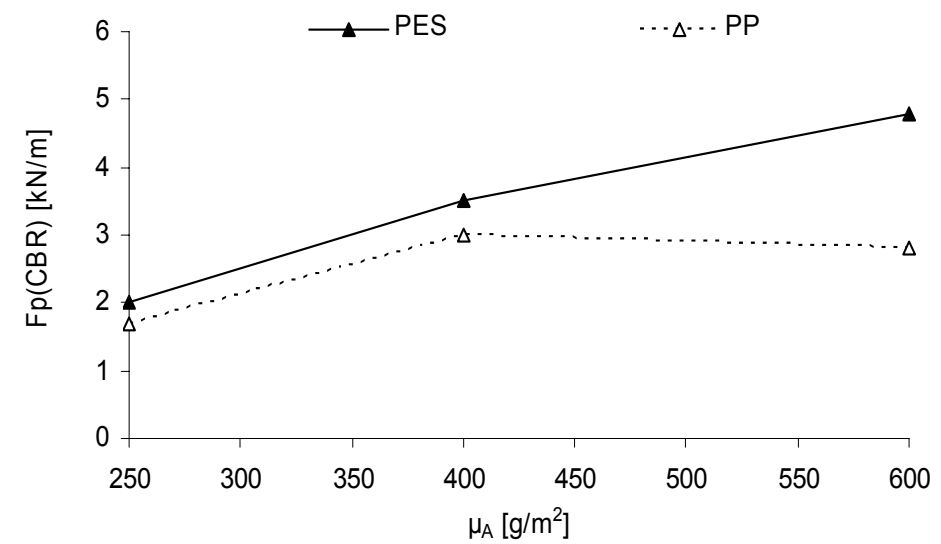

FIGURE 8 . The change of static puncture $\left(\mathrm{F}_{\mathrm{p}}-\mathrm{CBR}\right.$ method) of geotextiles between mass per unit area $\left(\mu_{\mathrm{A}}\right)$ of tested material

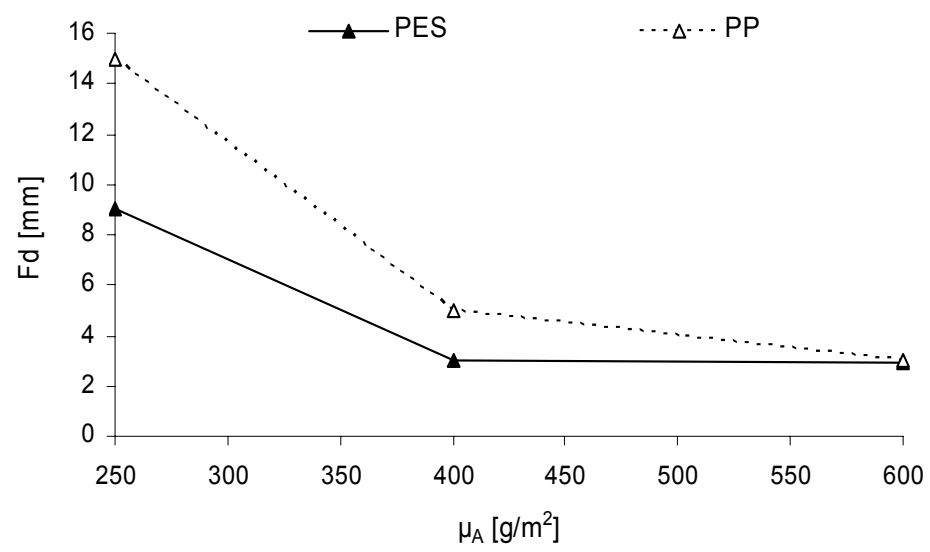

FIGURE 9. The change of dynamic puncture $\left(\mathrm{F}_{\mathrm{d}}\right)$ of geotextiles between mass per unit area $\left(\mu_{\mathrm{A}}\right)$ of tested material 


\section{CONCLUSIONS}

1. The technical parameters of tested geotextiles were depended on component materials and their production structure.

2. The values of transmissivity flow and tensile strength of tested geotextiles were depended on the direction of situated samples during tested.

3. The bulk densities, the thickness and the static punctures values of tested fabrics increased in tested material together with the increase of values of mass per unit area of investigated product.

4. The parameters of tested geotextiles as: the porosity, the apparent opening size, the velocity index flow and dynamic puncture in fabrics decreased when mass per unit area of tested products was increased.

\section{REFERENCES}

KRZYWOSZ Z., WOJTASIK D. 2001: Methodology of testing the permeability normal to the plane of nonwoven geotextiles. Ann. Warsaw Univ. of Life Sci. - SGGW, Land Reclam. No 31, 57-64.

ROLLIN A.L. 1986: Filtration opening size of Geotextiles. ASTM Standardization News, 50-52.

Yeo K.C. 2008: Properties of geotextiles. Castco Testing Centre Limited, Hong Kong (www.hkpc.org/hkiemat/ mastec 03 notes $/ 27$.pdf)

PN-EN ISO 9864: 2007 Geosyntetyki. Metoda badań do wyznaczania masy powierzchniowej geotekstyliów i wyrobów pokrewnych. (Geosynthetics. Test method for the determination of mass per unit area of geotextiles and geotextile - related products).
PN-EN ISO 9863-1: 2007 Geosyntetyki. Wyznaczanie grubości przy określonych naciskach - Część 1: Warstwy pojedyncze. (Geosynthetics. Determination of thickness at specified pressures - Part 1: Single layers).

PN-EN ISO 12956: 2002 Geotekstylia i wyroby pokrewne. Wyznaczanie charakterystycznej wielkości porów. Geotextiles and geotextile-related products. Determination of the characteristic opening size).

PN-EN ISP 11058: 2002 Geotekstylia i wyroby pokrewne. Wyznaczanie wodoprzepuszczalności w kierunku prostopadłym do powierzchniwyrobu, bez obciążenia. (Geotextiles and geotextile related products. Determination of water permeability characteristics normal to the plane, without load).

PN-EN ISO 12958: 2002 Geotekstylia i wyroby pokrewne. Wyznaczanie zdolności przepływu wody w płaszczyźnie wyboru. (Geotextiles and geotextiles and geotextile-related products. Determination of water flow capacity in their plane).

PN-EN ISO 10319: 2008 Geosyntetyki. Badanie wytrzymałości na rozciaganie metodą szerokich próbek. (Geotextiles - Wide width tensile test).

PN-EN ISO 12236: 2007 Geosyntetyki. Badanie statycznego przebicia - metoda CBR. (Geotextiles and geotextile related products. Static puncture test - CBR test).

PN-EN ISO 13433: 2007 Geosyntetyki. Badanie dynamicznego przebicia - metoda spadającego stożka. (Geosynthetics. Dynamic perforation test - cone drop test).

Streszczenie: Analiza fizycznych, hydraulicznych i mechanicznych wtaściwości igłowano-przeszywanych geowłóknin. W artykule przedstawiono analizę parametrów technicznych geowłóknin igłowano-przeszywanych, wykorzystywanych w konstrukcjach inżynierskich. Testy przepro- 
wadzono dla sześciu materiałów należących do dwóch grup produktów. Pierwsza grupa to geowłókniny powstałe na bazie polipropylenu, druga grupa to materiały syntetyczne z poliestru. Badane materiały posiadały masę powierzchniową 250 , 400 i $600 \mathrm{~g} / \mathrm{m}^{2}$. Przeprowadzona analiza badań geowłóknin igłowano-przeszywanych wskazuje, iż skład surowcowy oraz kierunek produkcji włókien wpływa na parametry techniczne materiałów syntetycznych.
MS. received November 2008

\section{Author's address:}

Dariusz Wojtasik

Katedra Geoinżynierii - SGGW

02-776 Warszawa, ul. Nowoursynowska 159

Poland

e-mail: dariusz_wojtasik@sggw.pl 